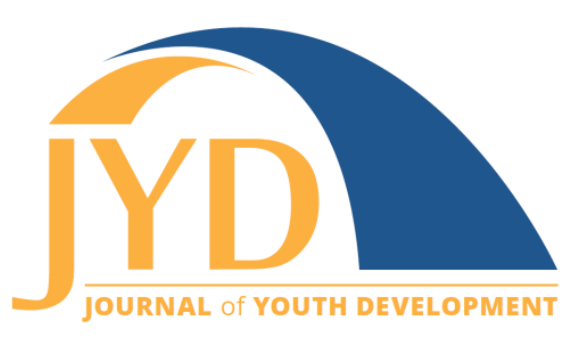

http://jyd. pitt. edu/ | Vol. 13 Issue 3 DOI 10.5195/jyd.2018.653 | ISSN 2325-4017 (online)

\title{
YA4-H! Youth Advocates for Health: Youth Participatory Action Research
}

\section{Theresa M. Ferrari}

The Ohio State University

ferrari.8@osu.edu

\begin{abstract}
Youth participatory action research is a process that is particularly relevant for health-related topics. YA4-H! Youth Advocates for Health: Youth Participatory Action Research is a resource that youth development professionals can use to guide a group through such a project. The 124-page curriculum is based on key principles of youth development and youth participatory action research. It has 7 sections, each with activities built on the same template that includes the time needed, materials, and facilitator tips, which contributes to ease of use. Youth development professionals can feel confident knowing that the curriculum is research based and addresses adolescents' developmental needs.
\end{abstract}

Key words: youth participatory action research, health, youth-adult partnerships

\section{Introduction}

Youth participatory action research (YPAR) has become a popular approach for engaging youth in the exploration of community issues, with the ultimate goal of creating community change (Ozer, 2016a, 2016b). In general, participatory action research is a collaborative process that has three components (Ozer, 2016a, 2016b; Ozer, Ritterman, \& Wanis, 2010; Powers \& Allaman, 2012; Rodriquez \& Brown, 2009):

- investigating meaningful social topics,

- participating in research to understand the root causes of problems, and

- $\quad$ taking leadership to disseminate the research findings to policymakers and stakeholders.

(c) $\mathbf{E Y}$ New articles in this journal are licensed under a Creative Commons Attribution 4.0 License. This journal is published by the University Library System, University of Pittsburgh and is cosponsored by the University of Pittsburgh Press. The Journal of Youth Development is the official peer-reviewed publication of the National Association of Extension 4-H Agents and the National AfterSchool Association. 
YPAR has been used to investigate a wide array of health issues, including tobacco use (HainesSaah, Oliffe, White, \& Botoroff, 2013; Jardine \& James, 2012), quality of school lunches (Reich, Kay, \& Lin, 2015), environmental health (Madrigal et al., 2014), teen pregnancy (Noone et al., 2016), and suicide prevention (Lindquist-Grantz, 2017). Data collection methods are varied, ranging from observation and surveys, to interviews and focus groups, to photovoice and mapping techniques.

\section{Curriculum Description}

The Youth Participatory Action Research (YPAR) curriculum (Arnold \& Gifford, 2015) is based on a youth-adult partnership model. It is one of three components of YA4-H! Youth Advocates for Health (YA4H), a teen leadership program developed at Oregon State University. The other two companion pieces address building successful youth-adult partnerships (Arnold \& Gifford, 2014; Flesch, Lile, \& Arnold, 2016) and teens as teachers (Arnold \& Gifford, 2015; Arnold et al., 2016; Flesch, Lile, \& Arnold, 2015).

\section{Background}

Key principles and a solid grounding in youth development research form the foundation of the curriculum. Youth leadership is crucial throughout participatory action research projects; thus, the authors note that a background in youth-adult partnerships is a prerequisite for successfully engaging in these projects (Arnold \& Gifford, 2015). This does not mean that adults turn everything over to youth, but that there is shared power and give-and-take in the process (Ozer, 2016b). Table 1 summarizes key principles guiding YPAR projects as identified in the curriculum. 
Youth Participatory Action Research

Table 1. Key Principles Guiding the Youth Participatory Action Research Curriculum (Anyon, Bender, Kennedy, \& Dechants, 2018; Arnold \& Gifford, 2015)

\begin{tabular}{|c|c|}
\hline Principle & Description \\
\hline Participation & $\begin{array}{l}\text { Programs engage youth in partnership with adults to experience the full } \\
\text { cycle of social science research, from problem identification to taking } \\
\text { action. }\end{array}$ \\
\hline Inquiry & $\begin{array}{l}\text { - Programs engage youth to think critically about issues that affect them } \\
\text { and their communities. } \\
\text { - Programs are active, where research is the means to an end, and the } \\
\text { knowledge created is translated into action } \\
\text { - Programs are practical; they address real community issues }\end{array}$ \\
\hline Transformation & $\begin{array}{l}\text { - Programs help youth envision the future and create change. } \\
\text { - Programs emphasize social justice and empowerment of youth. } \\
\text { - Programs directly engage youth, and thus may be more effective in } \\
\text { eliminating health disparities. }\end{array}$ \\
\hline
\end{tabular}

\section{Format}

The YPAR curriculum has seven sections, plus an introduction and a handouts section (see Table 2). There is an emphasis on learning through interactive methods. All the activities include the time, materials, and facilitator tips, as well as the activity's purpose, skills developed, room set-up, instructions, and discussion questions. Activity instructions are detailed enough, but brief and to the point, which makes them easy to use.

The curriculum integrates the key processes of YPAR. Power sharing is one of these processes (Anyon, Bender, Kennedy, \& Dechants, 2018; Ozer et al., 2010), and it is embodied in the youth-adult partnership approach. Training and practice in research skills is another YPAR key process (Ozer, 2016a; Ozer et al., 2010). Thus, the section on data analysis is particularly relevant, as youth do not always get to participate in this aspect of a project (Foster-Fishman, Law, Lichty, \& Aoun, 2010; Shamrova \& Cummings, 2017). A third process is building alliances with stakeholders (Anyon et al., 2018), emphasized in the "Sharing Your Story" and "Taking Action" sections. The "Reflection and Evaluation" section completes the experiential learning cycle. 
Youth Participatory Action Research

Table 2. Description of Youth Participatory Action Research Curriculum Contents (Arnold \& Gifford, 2015)

\begin{tabular}{|c|c|c|}
\hline Section & $\begin{array}{l}\text { Number of } \\
\text { activities }\end{array}$ & Description \\
\hline Introduction & -- & $\begin{array}{l}\text { Provides bacthe kground, outlines key principles, gives an } \\
\text { overview of a YPAR project, and provides a program logic } \\
\text { model. }\end{array}$ \\
\hline All Together Now! & 4 & $\begin{array}{l}\text { Includes activities designed to help participants get to know } \\
\text { each other so they can work together effectively; combining } \\
\text { this section with at least } 4 \text { hours from Building Youth-Adult } \\
\text { Partnerships (Arnold \& Gifford, 2014) is recommended. }\end{array}$ \\
\hline $\begin{array}{l}\text { Asking Questions: } \\
\text { What Do You Want to } \\
\text { Know? }\end{array}$ & 5 & $\begin{array}{l}\text { Engages youth in identifying areas of concern, selecting a } \\
\text { focus, and generating research questions. }\end{array}$ \\
\hline $\begin{array}{l}\text { Collecting and } \\
\text { Managing Data }\end{array}$ & 5 & $\begin{array}{l}\text { Reviews the various options for collecting data to answer } \\
\text { their research questions and gives opportunities to practice } \\
\text { collecting data by observation, interviews, surveys, and focus } \\
\text { groups. }\end{array}$ \\
\hline $\begin{array}{l}\text { Making Sense of It All: } \\
\text { Analyzing Your Data }\end{array}$ & 2 & $\begin{array}{l}\text { Illustrates techniques for organizing, analyzing, and } \\
\text { summarizing data. }\end{array}$ \\
\hline $\begin{array}{l}\text { Sharing Your Story: } \\
\text { Communicating Your } \\
\text { Research }\end{array}$ & 3 & $\begin{array}{l}\text { Helps youth summarize and prepare to present their process } \\
\text { and findings to appropriate audiences. }\end{array}$ \\
\hline $\begin{array}{l}\text { Taking Action: Using } \\
\text { Research to Improve } \\
\text { Your Community }\end{array}$ & 2 & $\begin{array}{l}\text { Helps youth identify stakeholders and analyze potential } \\
\text { barriers and facilitating factors, with an emphasis on decision } \\
\text { making, strategic planning, and teamwork. }\end{array}$ \\
\hline $\begin{array}{l}\text { Reflection and } \\
\text { Evaluation }\end{array}$ & 4 & $\begin{array}{l}\text { Aids in reflecting on what was learned and how to apply it in } \\
\text { other settings. }\end{array}$ \\
\hline Handouts & -- & $\begin{array}{l}\text { Contains handouts that correspond to specific activities in the } \\
\text { curriculum; handouts are listed under the materials heading } \\
\text { in each activity as needed. In addition to the handouts, there } \\
\text { are supplemental materials on a website } \\
\text { http://oregon.4h.oregonstate.edu/projects/ya4-h/research }\end{array}$ \\
\hline
\end{tabular}




\section{Considerations for Youth Development Professionals}

Research points to outcomes associated with YPAR at the individual, organizational, and community levels (Anyon et al., 2018; Ozer, 2016b; Ozer, 2017; Ozer et al., 2010; Shamrova \& Cummings, 2017). A recent review concluded that it is likely the principles and processes involved in YPAR, rather than the research topic, that generate these results (Anyon, et al., 2018). In addition to these benefits, youth development professionals should consider the following points:

1. Having a high quality, organized curriculum available can be a deciding factor for whether to tackle a complex process such as YPAR. Although there are multiple sources and toolkits outlining YPAR concepts and the steps involved, actually having the activities to provide structure for the process sets the YPAR curriculum apart.

2. Although all youth will benefit from this approach, YPAR may have particular relevance for audiences considered to be underserved or marginalized (Anyon et al., 2018).

3. Those who want to undertake a YPAR project should consider the time commitment involved. Community change takes time, and therefore YPAR requires multiple sessions. The YPAR curriculum provides a suggested timetable. If the group has not worked together previously, it may take even more time to build a foundation of a trusting relationship between youth and adults. The curriculum is designed to span an academic year, and it could be used in community or in-school settings (Ozer et al. [2010] discuss the benefits and challenges of both settings).

4. The data collection methods included in the curriculum are observation, survey, interviews, and focus groups. Those interested in other YPAR techniques, such as photovoice and mapping, will need to supplement this curriculum with other resources (e.g., Partnership for the Public's Health, 2009).

\section{Conclusion}

The benefits of YPAR make it worthy of consideration by youth development professionals. Youth development professionals who take advantage of this resource will not only find it easy to use, they can feel confident knowing that it is research based and by design addresses adolescents' developmental needs. 


\section{Ordering Information}

Title: YA4-H! Youth Advocates for Health: Youth Participatory Action Research

Contact: Mary E. Arnold, Ph.D.

Ballard Extension Hall 105, 2591 SW Campus Way

Corvallis, OR 97331

541-737-1315

mary.arnold@oregonstate.edu

Cost: $\$ 80+\$ 5$ shipping to continental United States

\section{References}

Anyon, Y., Bender, K., Kennedy, H., \& Dechants, J. (2018). A systematic review of youth participatory action research (YPAR) in the United States: Methodologies, youth outcomes, and future directions. Health Education and Behavior. doi: 10.1177/1090198118769357

Arnold, M. E., Flesch, J. M., Ashton, C., Black, L., Brody, B., Hosty, M., \& Northway, S. (2016). YA4-H! Youth advocates for health: Impact of a 4-H teens-as-teachers program. Journal of Extension, 54(6), Article 6RIB5. Retrieved from https://www.joe.org/joe/2016december/rb5.php

Arnold, M. E., \& Gifford, L. N. (Eds.). (2014). YA4-H! Youth advocates for health: Building successful youth-adult partnerships. Corvallis: Oregon State University Public Health Extension.

Arnold, M. E., \& Gifford, L. (Eds.). (2015). YA4-H! Youth advocates for health: Youth participatory action research. Corvallis: Oregon State University Public Health Extension.

Flesch, J. M., Lile, J. R., \& Arnold, M. E. (2015). YA4-H! Youth advocates for health: Teens as teachers. Journal of Youth Development, 10(2), Article151002RR001. doi: 10.5195/jyd.2015.414

Flesch, J. M., Lile, J. R., \& Arnold, M. E. (2016). Review of the YA4-H! Youth advocates for health: Building successful youth-adult partnerships training curriculum. Journal of Youth Development, 11(1), Article 161101RR003. doi: 10.5195/jyd.2016.440

Foster-Fishman, P., Law, K. M., Lichty, L. F., \& Aoun, C. (2010). Youth ReACT for social change: A method for youth participatory action research. American Journal of Community Psychology, 46, 67-83. doi: 10.1007/s10464-010-9316-y

Haines-Saah, R. J., Oliffe, J. L., White, C. F., \& Botoroff, J. L. (2013). "It's just not part of the culture here": Young adults' photo-narratives about smoking, quitting, and healthy lifestyles in Vancouver, Canada. Health and Place, 22, 19-38. doi: 10.1016/j.healthplace.2013.02.004 
Jardine, C. G., \& James, A. (2012). Youth researching youth: Benefits, limitations and ethical considerations within a participatory research process. International Journal of Circumpolar Health, 71, Article 18415. doi: 10.3402/ijch.v71i0.18415

Lindquist-Grantz, R. (2017). Youth participatory action research as a strategy for addressing adolescent suicide prevention. (Unpublished doctoral dissertation). University of Cincinnati, Ohio. Retrieved from http://rave.ohiolink.edu/etdc/view?acc_num=ucin149131648280023

Madrigal, D., Salvatore, A., Casillas, G., Casillas, C., Vera, I., Eskenazi, B., \& Minkler, M. (2014). Health in my community: Conducting and evaluating photovoice as a tool to promote environmental health and leadership among Latino/a youth. Progress in Community Health Partnerships, 8(3), 317329. doi: $10.1353 /$ cpr.2014.0034

Noone, J., Sullivan, M., Castillo McKinnis, N., Allen, T. L., Regalado, C., \& Esqueda, T. (2016). Latino youth participation in community-based participatory research to reduce teen pregnancy disparities. Children and Youth Services Review, 63, 36-39. doi: 10.1016/j.childyouth.2016.02.011

Ozer, E. J. (2016a). Youth-led participatory action research. In L. A. Jason \& D. S. Glenwick (Eds.), Handbook of methodological approaches to community-based research: Qualitative, quantitative, and mixed methods (pp. 263-272). New York, NY: Oxford University Press.

Ozer, E. J. (2016b). Youth-led participatory action research: Developmental and equity perspectives. In S. S. Horn, M. D. Ruch, \& L. S. Liben (Eds.), Equity and justice in developmental science: Theoretical and methodological issues (pp. 189-207). J. B. Benson (Series Ed.), Advances in child development and behavior (Vol. 50). Cambridge, MA: Academic Press/Elsevier. doi: 10.1016/bs.acdb.2015.11.006

Ozer, E. J. (2017). Youth-led participatory action research: Overview and potential for enhancing adolescent development. Child Development Perspectives, 11(3), 173-177. doi: 10.111/cdep. 12228

Ozer, E., Ritterman, M. L., \& Wanis, M. G. (2010). Participatory action research (PAR) in middle school: Opportunities, constraints, and key processes. American Journal of Community Psychology, 46(1), 153-2-166.

Partnership for the Public's Health. (2009). Photovoice as a tool for youth policy advocacy. Retrieved from http://www.partnershipph.org/publications/

Powers, C. B., \& Allaman, E. (2012, December). How participatory action research can promote social change and help youth development (Berkman Center Research Publication No. 2013-10). Cambridge, MA: Berkman Klein Center for Internet \& Society at Harvard Law School. Retrieved from https://ssrn.com/abstract=2199500 
Journal of Youth Development | http://jyd.pitt.edu/ | Vol. 13 Issue 3 DOI 10.5195/jyd.2018.653 Youth Participatory Action Research

Reich, S. M., Kay, J. S., \& Lin, G. C. (2015). Nourishing a partnership to improve middle school lunch options: A community-based participatory research project. Family and Community Health, 38(1), 77-86. doi: 0.1097/FCH.0000000000000055

Rodriguez, L. F., \& Brown, T. M. (2009). From voice to agency: Guiding principles for participatory action research with youth. New Directions for Youth Development, 123, 19-34. doi: 10.1002yd.312

Shamrova, D. P., \& Cummings, C. E. (2017). Participatory action research (PAR) with children and youth: An integrative review of methodology and PAR outcomes for participants, organizations, and communities. Children and Youth Services Review, 81, 400-412. doi:

10.1016/j.childyouth.2017.08.022 